\title{
Retórica subalterna en Graciela Huinao y Conceição Evaristo a través de la metáfora de la voz
}

\author{
Subaltern rhetoric in Graciela Huinao and Conceição Evaristo through the voice metaphor \\ Retórica subalterna em Graciela Huinao e Conceição Evaristo através da metáfora da voz
}

Paola Lizana Miranda*

\section{Resumen}

En el presente análisis nos proponemos abordar los poemarios Walinto de Graciela Huinao y Poemas da recordação e outros movimentos de Conceição Evaristo, desde la perspectiva de la retórica subalterna, entendiendo esto como la evidenciación de las metáforas que subvierten el discurso colonizador. Acorde a ello, hemos vinculamos las obras de Huinao y Evaristo a través de la metáfora de la voz, la cual decimos configura el espacio común de apertura hacia lo otro, como eco, resonancia y/o grito, textualizando la preeminencia connotativa de las culturas orales y las concepciones contemporáneas de las subjetividades múltiples y plurales.

Palabras claves: retórica subalterna, oralidad, Graciela Huinao, Conceição Evaristo.

\begin{abstract}
In the current analysis, we intend to address Graciela Huinao's collection of poems Walinto and Conceição Evaristo's Poemas da recordação e outros movimentos from the subaltern rhetoric perspective. Understanding this as evidence of metaphors that subvert colonizing discourse. In accordance with it, we have linked the works of Huinao and Evaristo through the metaphor of the voice. Which we say configures the common space of openness towards the other, as an echo, resonance and/or scream, textualizing the connotative privilege of oral cultures and the contemporary conceptions of the multiple and plural subjectivities.
\end{abstract}

Keywords: Subaltern rhetoric, orality, Graciela Huinao, Conceição Evaristo.

\begin{abstract}
Resumo
$\mathrm{Na}$ presente análise, nós propomos abordar os poemas Walinto de Graciela Huinao e Poemas da recordação e outros movimentos de Conceição Evaristo, na perspectiva da retórica subalterna, entendendo isso como evidência das metáforas que subvertem o discurso colonizador. De acordo com isso, vinculamos as obras de Huinao e Evaristo por meio da metáfora da voz, que nós afirmamos configurar o espaço comum de abertura com o outro, como eco, ressonância e/ou grito, textualizando a preeminência conotativa das culturas orais e concepções contemporâneas de subjetividades múltiplas e plurais.
\end{abstract}

Palabras-clave: retórica subalterna, oralidade, Graciela Huinao, Conceição Evaristo.

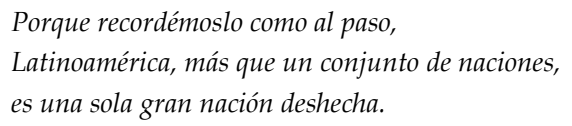

Ziley Mora

\section{Introducción}

En el presente análisis nos proponemos vincular Walinto (Huinao, 2009) y Poemas da recordação e outros movimentos (Evaristo, 2008), poemarios pertenecientes a letras mapuches y afrobrasileñas respectivamente. Respecto de ello, planteamos que en las obras de Huinao y Evaristo la voz se constituye en metáfora de cultura, habla y lenguaje, así como también de

\footnotetext{
* Universidad de Ciencias de la Educación de Playa Ancha, Valparaíso, Chile. Dorcid.org/0000-0002-0936-5124. E-mail: plizanam5@hotmail.com
} 
identidad. Conforme a lo anterior, afirmamos que en los poemarios analizados la cadena semántica que alude a la voz, a través de los significantes referidos al canto, lengua, eco, resonancia y poesía entrelazan el destino colectivo e individual de las hablantes líricas de ambos textos, nombrando la diferencia étnica y genérica de las sujetos colonizadas. Cabe señalar que, en este análisis, hemos denominado como retórica subalterna ${ }^{1}$ a la evidenciación de metáforas que subvierten el discurso colonizador.

Pues bien, atendiendo a lo anterior, planteamos que la voz como metáfora, junto a todas sus alusiones semánticas, refiere alegóricamente a la oralidad de los pueblos ancestrales, recomponiendo en los textos las coordenadas geográficas y simbólicas de los pueblos mapuche y africanos. Relacionado con lo anterior decimos, la metáfora de la voz enuncia la tensión existente entre la preeminencia del significante en una cultura letrada y la proliferación de significados propia de la oralidad originaria. Por otra parte, afirmamos que la cadena significante referida a la oralidad ilumina aquella zona liminal de preeminencia connotativa o de la diferencia o differánce. Respecto de ello podemos plantear que Derrida $(1968$, p. 17) señala que "el uno no es más que el otro diferido, el uno diferente del otro. El uno es el otro en la diferencia [differánce], el uno es la diferencia [differánce] del otro". De este modo afirmamos que en los poemarios de Huinao y Evaristo se enuncia una sujeto que nombra su diferencia de mujer mapuche y afrobrasileña como articulación de voces plurales, lo que decimos alude a los planteamientos contemporáneos y decoloniales, en tanto desborde de las concepciones duales y jerárquicas del sistema lingüístico y sus consideraciones ontológicas.

Respecto de la voz como metáfora, podemos señalar que por un lado es un don colectivo, a través de la cual se vinculan las formas culturales de una sociedad manifestando su organización y complejidad. Por otra parte, también es posible sostener que en ella se expresa la máxima singularidad, en tanto a través de la voz se piensa, produce sentido y habla el "yo". Conforme a lo anterior, afirmamos que dicha metáfora manifiesta el destino individual de quien se enuncia, destino que se vuelve colectivo cuando se articulan varias voces. En este sentido, es posible afirmar que en los textos analizados voz, palabra, lengua, eco, grito; entre otros significantes, funcionan como recursos retóricos que refieren a la tensión existente entre la oralidad originaria y la palabra escrita colonizadora. Respecto de ello, cabe señalar que Ángel Rama precisa que la imposición de la escritura por sobre la validez de la oralidad de las culturas ágrafas, implica un cambio epistémico que va a marcar la entrada a la historia moderna del mundo occidental y sus colonias. En este sentido este autor hace coincidir este momento de hegemonía de la palabra escrita con la instalación del poder imperial en el continente:

Esta palabra escrita viviría en América Latina como única valedera, en oposición a la palabra hablada que pertenecía al reino de lo inseguro y precario [...] La escritura poseía rigidez y permanencia, un modo autónomo que remedaba la eternidad. Estaba libre de las vicisitudes y metamorfosis de la historia, pero, sobre todo, consolidaba el orden por su capacidad para expresarlo rigurosamente en el nivel cultural (1998, p. 22).

Considerando los dichos anteriores, donde se enfrenta la precariedad de la palabra hablada con la permanencia de la escritura, es posible plantear que Rama refiere a la colonización epistémica como un proceso lingüístico donde la permanencia de la letra escrita se impone a la preeminencia connotativa de la oralidad originaria. Además, cabe referir, que dicho cambio epistémico implica la disolución de los lazos que unían las palabras a las cosas, cediendo al binarismo jerárquico de la palabra lógica, lo que en la cita anterior queda manifestado como oposición entre permanencia del signo escrito y la inseguridad de la palabra oral. En consideración a esto último, afirmamos que es posible vincular los textos que conforman nuestro corpus a través de la metáfora de la voz como alegorización del espacio liminal que refiere a formas epistémicas anteriores/diferentes a la preeminencia de la escritura, donde a través de la cadena semántica, canto, palabra, eco, lengua y grito, entre otros, decimos, se

\footnotetext{
${ }^{1}$ Hacemos presente que este concepto fue desarrollado en el trabajo Retórica o poética subalterna en la obra de Teresa Calderón a través de la reconfiguración de las metáforas de la casa y del espejo, Tesis para optar al grado de Doctora en Literatura Hispanoamericana Contemporánea, investigación financiada por Beca Doctorado Nacional 2018, Comisión Nacional de Investigación Científica y Tecnológica (Conicyt).
} 
restituyen las potencias analógicas de la oralidad originaria, a través de la proliferación connotativa de la palabra poética, emergiendo con ello dentro de los textos una sujeto que nombra la diferencia cultural y genérica de las hablantes. Ahora bien, en conformidad a lo anterior y al corpus que abordaremos en este análisis, pertenecientes a la producción escritural contemporánea mapuche y afrobrasileña respectivamente, creemos necesario configurar a grandes trazos la experiencia y el sentir indígena y africano del mundo, cristalizado en ambos casos por medio de una larga tradición oral.

\section{La voz como metáfora en Walinto de Graciela Huinao}

Respecto de Graciela Huinao podemos señalar que es una poeta y narradora de origen williche-mapuche, perteneciente a la comunidad de Walinto, la misma que otorga el título a su primer libro de poemas, el que abordamos en el presente análisis. Su carrera literaria se inició con la publicación del poemario Walinto en 2001, para continuar más tarde con el lanzamiento de los cuentos La nieta del brujo, seis relatos williche en 2003, y las novelas Desde el fogón de una casa de putas williche en 2010 y Katrilef, hija de un ülmen mapuche williche. Relato de su vida en 2015. En la actualidad, esta autora se ubica en un lugar de importancia dentro de las letras chilenas y mapuche, siendo la primera mujer de su etnia en publicar libros de poesía y relatos traducidos al inglés. Además, dentro de sus logros se puede señalar que desde el año 2014, es la primera mujer mapuche miembro de la Academia Chilena de la Lengua. Los reconocimientos antes mencionados ejemplifican sintéticamente la atención que han obtenido sus méritos como poeta y narradora.

Ahora bien, en relación a la oralidad fundante de la cultura mapuche desde donde se enuncia la voz lírica de Walinto, Iván Carrasco Munõz (2010, p. 28), nos recuerda que esta sociedad es una cultura eminentemente verbal, que se expresa principalmente en una lengua compleja, musical, apta para la oratoria de diversos caracteres, cotidiana, familiar, pública, social, bélica, intercultural; una etnoliteratura conformada por diversos géneros, epeu, ül, etc., ${ }^{2}$ y una literatura propiamente tal en español, en mapudungun o en una expresión mixta. Así mismo este autor, señala que en la etnoliteratura oral, tradicional, ancestral, memorística en lengua mapudungun, propia de la oralidad absoluta, tiene como género clave el epeu en sus diversas variedades: mítico, épico, de aventuras, de personajes, didáctico, etnográfico etc. Con lo anterior este autor da cuenta de la diversidad de formas expresivas que vehiculizan a través de la palabra los saberes de este pueblo. ${ }^{3}$

Conforme a lo anterior, en este análisis nos centramos en la metáfora de la voz, que decimos en el poemario Walinto se nos presenta como recurso retórico que alude a la preeminencia oral de la cultura mapuche, donde el mapuzungun funciona como el principal elemento unificador de los distintos territorios que conviven en el wallmapu. ${ }^{4}$ De acuerdo a ello, ponemos en perspectiva la complejidad y diversidad de la sociedad mapuche, cuyo abordaje supera largamente los objetivos de este trabajo, aunque sí podemos señalar que desde el punto de vista literario se pueden percibir algunas temáticas que unifican la producción poética y narrativa. Respecto de esto último, Mora Curriao indica que la reivindicación de lo mapuche ancestral, la memoria, el origen familiar (küpalme), el territorio de origen (tuwun) la lengua propia (mapudungun) como elementos articuladores de esta poética (2018, p. 172). En nuestro análisis nosotros planteamos que los elementos a los que refiere la investigadora, en el poemario Walinto, se reúnen a través de la metáfora de la voz, la cual alude a la oralidad ancestral que con su pluralidad significante se opone a la palabra escrita. Al respecto Ziley Mora (2001) señala que la verdad del ser mapuche se

\footnotetext{
${ }^{2}$ Los epeu, epew o apew es un tipo de relato mapuche en que se narran sucesos ficticios, habitualmente protagonizados por animales personificados. En tanto, los $\ddot{u} l$ son los cantos tradicionales mapuches.

${ }^{3}$ Así mismo Graciela Huinao refiriéndose a la tradición oral de su pueblo señala: "La historia estaba en el núcleo familiar, de fogón en fogón. Y yo la quise escriturar. Si mi abuela la hubiese escrito, ella habría sido la poeta. Yo traspaso lo que me han contado y contado desde lo mapuche: hago un traspaso de mi memoria" (Huinao apud Mosciatti, 2012, p.1).

${ }^{4}$ Respecto de ello cabe recordar que tal como señala Mora Curriao, el mapa del "País araucano" ya desde antes de la conquista española había comenzado a desmembrarse, acentuando las diferencias de las diversas identidades territoriales: williche, pewenche, lafkenche, nagche, entre otras (Mora Curriao, 2018, p. 172).
} 
delinea a través de la pluralidad significante del mapudungun. Respecto de ello, Mora nos recuerda que la estrategia araucana para arrebatar la verdad, es decir, para descorrer los velos que tapan la revelabilidad de la identidad humana, es conectar e integrar en un solo lexema, en una sola palabra, diversas metáforas, que a su vez recogen y contienen por sí mismas sus propias alusiones o metáforas, dándole a las palabras una extraordinaria polisignificancia (2001, p. 27). ${ }^{5}$ Acorde a lo anterior, planteamos que esta zona de proliferación de sentidos, donde cada término completa su significante en comunicación con el otro, vincula la polisignificancia de la oralidad originaria y los conceptos contemporáneos de la diferencia, lo que decimos se hace presente en el poema "La voz de mi padre" como enunciación de un lenguaje indómito:

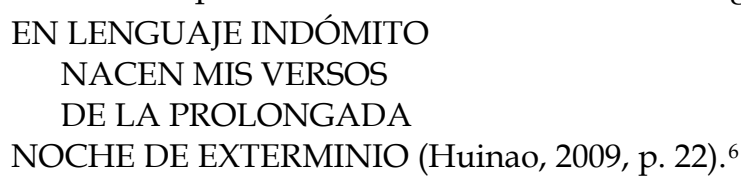

Respecto de los versos citados, planteamos que, en el título del poema, la alusión a la voz del padre de la hablante, revindica las conformación tradicional del pueblo mapuche, fundada en lazos filiales y sanguíneos. Por otra parte, creemos que por medio de la referencia al lenguaje indómito y al hacer poético expresado en los primeros versos, esto último como nacimiento de versos, NACEN MIS VERSOS en palabras de la hablante, planteamos hacen radicar en la palabra oral/ancestral y en la palabra poética, la potencialidad de resistir a la destrucción colonizadora, lo que en el poema se expresa como larga noche de exterminio. Respecto del dominio colonial, como ya antes señalábamos, la colonización epistémica se puede entender como imposición de la rigidez y permanencia de la letra escrita sobre la preeminencia connotativa de las oralidades originarias. Dicha rigidez y permanencia devenida de la univocidad significante radicada en la denotación, decimos es desbordada por la palabra oral/ancestral y la poesía por su polisignificancia y/o multiplicidad de significados. En relación a esto último creemos relevante referir a la orgánica relación entre oralidad y poesía establecida por Gérard Genette (1970), quien plantea que este último es el género de la declamación por excelencia, lenguaje poético, que siguiendo la orientación norma-anomalía corresponde a todo lo que escapa de los marcos de la lingüística denotativa (1970, p. 5). ${ }^{7}$ Por otra parte, en referencia al lenguaje ancestral del pueblo mapuche, como ya habíamos mencionado, cabe señalar que es este un registro idiomático ágrafo en su origen, también que el mapudungun es el principal elemento de unión de los diversos territorios culturales que conviven en el wallmapu. Así mismo como ya antes señalábamos el fonema en mapudungun rebasa en su multiplicidad connotativa las clausuras del lenguaje lógico. Respecto de lo anteriormente planteado, Mora señala que la lengua mapuche es el gran vehículo de la cosmovisión y las prácticas ceremoniales, en este sentido la base estructural de la lengua mapuche se funda en fecundos paradigmas creadores de realidades, que constituyen estructuras epistemológicas que superan el agotado y limitado racionalismo dualista occidental (2001, p. 9). Es en este sentido, que en este análisis, bajo nuestra perspectiva de la retórica subalterna, entendiendo esto último como evidenciación de metáforas que subvierten el discurso colonizador, afirmamos que en los textos, la metáfora de la voz alegoriza la multisignificancia de la palabra oral/ancestral y la palabra poética, iluminando el espacio connotativo liberado de la rigidez y permanencia de la letra escrita colonizadora, palabra liberada que constituye el lenguaje indómito al que refiere la hablante. Planteamos en este sentido que en Walinto voz, lengua, poesía y canto; conforman una cadena metonímica cuyo significado refiere a la oralidad de los pueblos ancestrales y a las

\footnotetext{
${ }^{5}$ Mora ejemplifica dicha polisignificancia a través del concepto del "yo" en la lengua mapuche, donde la palabra "inche" (yo) alude al "mundo de abajo" (minche), al "alimentarse", en tanto "in" refiere a lo que está dentro o se procesa por dentro, tal como la asimilación de los alimentos y "che" a la abundancia o riquezas de lo humano (2001, p. 27).

${ }^{6}$ El poema original está escrito en mayúscula, lo que sin duda abre variadas claves de interpretación que, por motivos de extensión, no hemos abordado en el presente trabajo, dejando consignado este hecho para un posterior análisis.

${ }^{7}$ En relación a ello Genette señala: "La poesía antigua era esencialmente cantada (lirismo) y recitada (epopeya) y que, por razones materiales muy evidentes, el modo de comunicación literaria fundamental, aún para la prosa, era la lectura o declamación pública, dejando a un lado el papel preponderante que asumía, en la prosa, la elocuencia propiamente dicha" (1970, p. 6).
} 
subjetividades múltiples contemporáneas. Así creemos evidenciarlo nuevamente en el poema "Los cantos de José Loi" que citamos a continuación:

Vuelven

(A mi bisabuelo)

en primavera

donde el campo generoso

honra con árboles

el paso inmortal

de mis abuelos

Los cantos de mi padre

cuando borracho de sueños

en el país de mi infancia

me enseñaba la ruta

que siguen las estrellas.

A veces lágrimas

traían las noches de invierno

al enseñarme a descifrar

los cantos de la montaña

a comunicarme con los pájaros

en su idioma infinito

$\mathrm{y}$ a entender

el mensaje del viento

en remolino sobre el río.

Ahora

acuñando sus cantos

a mi vestido digo:

La primera escuela de mi raza

es el fogón

en medio de la ruka

donde arde

la historia de mi pueblo (Huinao, 2009, p. 59).

Conforme a lo hasta aquí planteado, la lengua tradicional del pueblo mapuche rebasa las estructuras duales del logos occidental, diseminando las significaciones en la pluralidad de sentidos desplegados por los fonemas del mapuzungun, diseminación significante que ha momentos en el texto, encuentra como vehículo de restitución y/o conservación la palabra poética. Así creemos evidenciarlo en los versos del poema citado donde se establece dicha restitución como regreso, tal como acontece a través de la elocución -vuelven en primavera - aludiendo a los cantos de José Loi, bisabuelo de la autora, según se precisa en el epígrafe que abre el poema. Ahora bien, decimos así mismo que el dugun, habla o decir, es alegorizado en el poema como canto que transmite el kimun o sabiduría ancestral de generación en generación, así creemos queda evidenciado con la imagen del fogón en medio de la ruka, ${ }^{8}$ el que se identifica como la primera escuela de esta raza, en alusión a la oralidad como forma de conservación y transmisión de la historia y el saber dentro de la comunidad tradicional mapuche. En este sentido cabe recordar que para las culturas ágrafas como la mapuche la palabra posee dimensiones sagradas, por sus fuerzas de preservación del ethos y la cosmovisión aborigen, esto último a decir de Mora (2001, p. 7), refiere a lo que esta "cerca del origen" cerca del ser genuino de las cosas; del lenguaje primigenio de la naturaleza, la que establece sus verdades, sus correspondencias, sus leyes, sus ritmos y sus prácticas de un modo inapelable. Conforme a ello, afirmamos que en el poema antes citado el canto, apela a otras formas subjetivas donde el devenir humano se corresponde con el de la naturaleza, lo que en los versos citado decimos se presenta como el descifrar de la hablante de los cantos de la montaña, también como comunicación con el

\footnotetext{
${ }^{8}$ Ruca (del mapudungun ruka, "casa") es el nombre de la vivienda tradicional de los mapuches, pueblo que habita en los actuales territorios de Chile y Argentina.
} 
idioma infinito de los pájaros, y entendimiento de los mensajes del viento. Respecto de lo anterior, es decir la configuración literaria de otras formas subjetivas presente en la escritura poética de mujeres mapuche, Moraga (2009, p. 226) plantea que, dentro de una perspectiva de las identidades, concurren cruces entre género y etnicidades que resultan fundamentales en su relación con la construcción de subjetividades "diferentes", las que pervierten los estereotipos impuestos por el sistema occidental colonizador. Acorde a ello, nosotros planteamos que la subjetividad que emerge en las obras aquí analizadas se articula a través de la unión de voces plurales, como espacio común en apertura hacia otras voces que en el poema anterior se metaforiza como canto ancestral que resuena en la naturaleza. Comunión entre las voces originarias y naturales que creemos se reitera en el poema "Nawel buta":

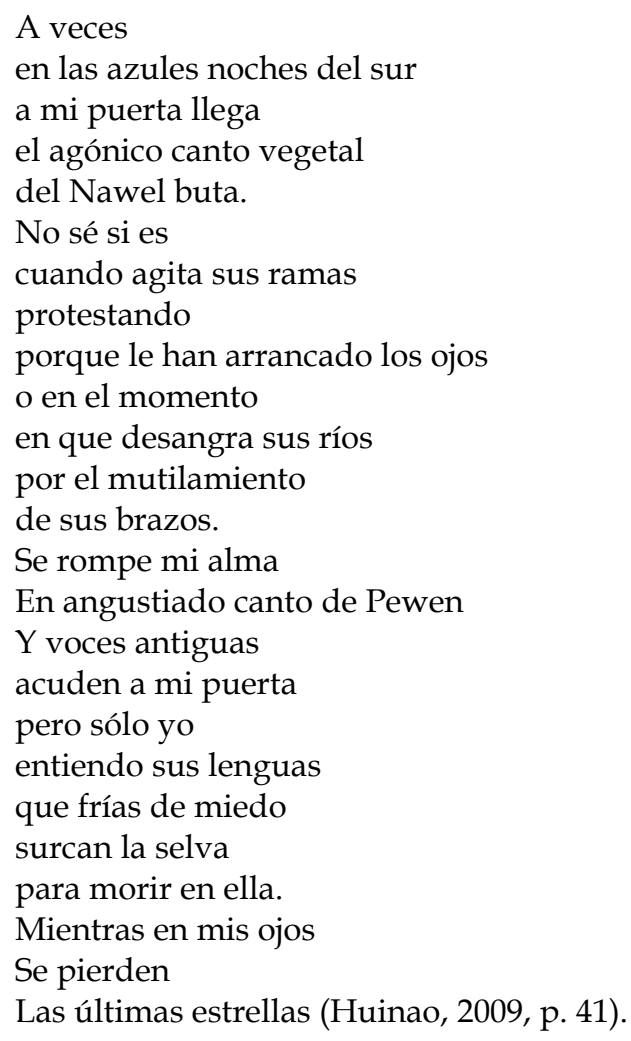

Pues bien, respecto del poema citado podemos señalar que Nawel buta es el nombre de la cordillera que se extiende desde la Región de Bio-bio hasta Valdivia, nominación que da título al poema y que según se precisa a pie de página significa "tigre grande". Así mismo también en cursiva, en el texto se hace mención al pewen, otro vocablo en lengua mapudungun, el cual se traduce como "árbol de la araucaria". A partir de lo anterior, es posible referir al registro multicultural que distingue la producción poética mapuche, así lo indica Iván Carrasco Munõz (2000, p. 200), señalando que la codificación plural característica de esta poesía es una estrategia discursiva que lleva implícita un doble destinatario y por lo tanto doble lectura, posible solo en el marco de una sociedad que reconozca la existencia de su carácter mestizo e intercultural. Siguiendo los planteamientos de Carrasco Munõz, esta doble textura lingüística a la que refiere el autor, codifica pluralmente una poética de resistencia en la producción lírica mapuche, ${ }^{9}$ gesto decolonial que en Walinto se configura en el espacio textual como multiplicidad idiomática, por medio de la irrupción de los vocablos en lengua originaria, como hemos ejemplificado anteriormente con el título del poema y las referencia al pewen. En este sentido afirmamos que la obra en análisis se configura como una red semántica múltiple desde el punto de vista de significados y sistemas lingüísticos, los que desplazan la geografía de exclusión/asimilación

\footnotetext{
${ }^{9}$ Dentro de las principales estrategias discursivas desarrolladas por letras etnoculturales Carrasco Muñoz (2000, p. 197) destaca que una de ellas es la codificación plural del texto, que ha adoptado la forma del doble registro y del collage etnolingüistico, gradación que abarca distintos niveles del acercamiento, integración y aculturación en el sur de Chile.
} 
impuesta por el mestizaje, en tanto intercambio cultural asimétrico. Relacionado con lo anterior, afirmamos que la polisemia lingüística del texto antes referida se alegoriza como enunciación discursiva de múltiples voces y lenguas, lo que desde el punto de vista contemporáneo refiere en el texto a la apertura del sistema lingüístico, otorgándole preeminencia a la connotación por sobre la denotación. Relacionado con lo anterior, nos referimos a los planteamientos de Derrida respecto de la diferencia o (différance), según el autor la conformación del sistema lingüístico presupone que todo signo presente solo es pensable a partir de la presencia diferida (Derrida, 1968). En consideración a ello, ningún término o signo es unívoco, sino que su significado se completa o construye en relación con otros términos, así decimos en los versos citado esta apertura se hacer presente a través la multiplicidad o pluralidad de lenguas y voces, las cuales se articulan para nombrar la diferencia de los espacios, tiempos y sujetos otros, silenciados por el discurso hegemónico y su pretendida univocidad significante. Dicha articulación decimos en los versos antes citados se presenta como voces antiguas que acuden a la puerta de la hablante y lenguas que surcan la selva, solo inteligibles para ella, imágenes que alegorizan la enunciación como espacio de comunicación donde la subjetividad emerge como unión de múltiples voces. Así mismo decimos la diferencia cultural desde donde se enuncia la voz lírica del texto de Huinao en los versos citado se nombra como como canto vegetal y/o canto del pewen, interpelando de este modo la enunciación logocéntrica de la tradición humanista.

\section{Poemas da recordação e outros movimentos de Conceição Evaristo}

Respecto de la metáfora de la voz en el texto Poemas da recordação e outros movimentos de Conceição Evaristo, creemos que esta se hace presente como eco, lamento, resonancia y/o grito; alegorizando de este modo la preeminencia de la oralidad de las culturas de origen africano. Respecto de lo anterior, cabe señalar que de la diversidad de pueblos africanos que llegaron al continente para ser esclavizados, parte central de sus manifestaciones religiosas y culturales estaban hechas para ser cantadas o recitadas. ${ }^{10}$ Pues bien, acorde a ello trazar el camino de la oralidad originaria de los pueblos afrodescendientes, significa realizar un viaje trasatlántico, donde además encontraremos los heterogéneos orígenes de la gran cantidad de hombres y mujeres traídos al continente para ser esclavizados. Respecto de esta heterogeneidad el profesor Paulo Thomaz nos recuerda:

No debemos ignorar que las 'naciones' africanas eran denominaciones atribuidas a pueblos que reunían enmarañadas y diferentes categorías lingüísticas, culturales y políticas. Eran mujeres y hombres que fueron unificados inicialmente para obedecer a los intereses comerciales de los traficantes de esclavos, aunque eso no quiere decir que no poseían afinidades en diferentes ámbitos. Sin embargo, los vínculos entre sí, reales o imaginados, estuvieron entre los motivos que hicieron que acabasen siendo reunidos de modo similar en diferentes países, como en Haití, en Cuba y en Brasil (2015, p. 26, traducción mía).

Pues bien, teniendo en cuenta dicha diversidad cultural, planteamos que la oralidad tradicional es un elemento articulador de la identidad afrodescendiente latinoamericana. En ese sentido tomamos también las palabras de la profesora Daiana Nascimento dos Santos (2011, p. 147), quien señala que la tradición africana oral se evidencia como significativo hincapié para la reconstrucción de su historia, elemento que vehicula su perpetuación que ha sido transmitida oralmente a través de los tiempos. Dicha transmisión del relato intergeneracional de la historia de mujeres emparentadas con la hablante, conforma el núcleo temático del poema "Vozesmulheres" de Conceição Evaristo que citamos a continuación:

A voz de minha bisavó

Ecoou criança

nos porões do navio.

\footnotetext{
${ }^{10}$ Ejemplo de ello, es la poesía adivinatoria de los pueblos Yorubá, cuya transmisión de forma oral a través de los siglos, permitió su supervivencia entre los esclavos americanos que compartían esta creencia. Su realización ortográfica, además es relativamente reciente, por lo que no ha adquirido aún la solidez necesaria para evitar las confusiones inherentes a su variada tipografía (Cardoso, 2015, p. 17).
} 
Ecoou lamentos

De uma infância perdida.

A voz de minha avó

Ecoou obediência

Aos brancos-donos de todo.

A voz de minha mãe

Ecoou baixinho revolta

No fundo das cozinhas alheias

debaixo das trouxas

roupagens sujas dos brancos

pelo caminho empoierado

rumo à favela.

A minha voz ainda

ecoa versos perplexos

com rimas de sangue

e

fome

A voz de minha filha

recolhe todas as nossas vozes

recolhe em si

as vozes mudas caladas

engasgadas nas gargantas

A voz de minha filha

recolhe em si

e fala e o ato.

O ontem - o hoje - o agora.

Na voz de minha filha

Se fará ouvir a ressonância

O eco da vida-liberdade (Evaristo, 2008, p. 24-25). ${ }^{11}$

Pues bien, respecto del poema antes citado, Duarte de Assis (2006) señala que desde su publicación en 1990 en los Cadernos Negros, los versos de "Vozes-mulheres" se constituyeron en una especie de manifiesto-síntesis de la poética de la autora. En este sentido es posible afirmar que el análisis de estos versos es ineludible en el intento de realizar un acercamiento a la poética de Evaristo. Cabe señalar también que esta poeta y narradora afrobrasileña es una de las autoras comprometidas con quebrar las imágenes estereotipadas con que el canon literario ha representado a la mujer-negra, esto es como cuerpo-procreación y/o cuerpo-objeto (Monteiro, 2021, p. 2). ${ }^{12}$ De allí decimos que darle voz a las hablantes y protagonistas de sus obras constituye una forma de reafirmar ese compromiso escritural de Evaristo. Relacionado con lo anterior, Feldman y Silvestre (2015, p. 97) plantean que en el poema citado la subjetividad de la hablante se constituye en el momento que descubre que su voz lleva las voces de otras generaciones y que esta voz existe y puede ser oída. Según lo antes planteado, en la enunciación de la hablante se articulan o entraman las voces de la bisabuela, la abuela, la madre y la hija, interpelando con ello la enunciación singular

\footnotetext{
${ }^{11}$ La voz de mi bisabuela/resonó niña/en los sótanos del navío/repitió lamentos /de una infancia pérdida. La voz de mi abuela/ repitió obediencia a los blancos-dueños de todo.

La voz de mi madre/Repitió bajito revuelta /En el fondo de las cocinas ajenas /Debajo del montón de /Ropas sucias de los blancos /Por el camino polvoriento /Rumbo a la favela /Mi voz todavía /Repite versos perplejos /Con rimas de sangre/Y hambre.

La voz de mi hija/recoge todas nuestras voces/las voces mudas calladas/ahogadas en las gargantas

La voz de mi hija/recoge en sí/el habla y el acto/El ayer-el hoy- el ahora/En la voz de mi hija/Se hará oír la resonancia/Del eco de vida-libertad (traducción mía).

${ }^{12}$ Respecto de ello la autora señala "A representação literária da mulher negra é ainda ancorada nas imagens de seu passado escravo, de corpo-procriação e/ou como corpo-objeto de prazer".
} 
del sujeto colonizador. Ahora bien, en referencia al título del poema, Rosana Arruda de Souza (2019, p. 14) indica que en este vislumbramos el signo mujer disociado de su carácter de presencia para volverse rastro, más específicamente como voz, que se extiende a un conjunto de voces ancestrales. En este sentido cabe recordar que bajo el análisis de esta investigadora el concepto de rastro, enmarcado bajo el deconstructivismo derridiano, da sentido a la exterioridad del signo cuando ilumina lo que quedo fuera del centro de la significación, es decir la no presencia, en este caso la vozeco-lamento de las mujeres negras esclavizadas y marginadas por la historia colonial. Este planteamiento de Arruda de Souza nos posibilita sostener que la comunicación intergeneracional planteada en el texto abraza las concepciones contemporáneas que conciben el lenguaje y las subjetividades como espacios liminales de apertura o referencia constante a lo otro, negando con ello las clausuras y jerarquías logocéntricas. En este mismo sentido de contemporaneidad, Thomaz (2015, p. 24) indica que Evaristo es una de las escritoras afrodescendientes recientes, capaz de representar discursivamente de modo "inédito" la historia de la esclavización negra y colocarla en relación con otros tiempos, formulando y negociando un sentido para las culturas mixtas y diaspóricas que constituyen la sociedad brasileña del presente, con especial atención en la cuestión de género. Lo antes referido por Thomaz, creemos se hace evidente en el poema "Vozes-mulheres", en el cual sus dos primeras estrofas dan cuenta del viaje esclavista de la bisabuela y el trabajo en la casa grande de la abuela. Así mismo, la esclavitud de las antepasadas se pone en relación con el presente de la hablante, la que repite versos perplejos con rimas de sangre y hambre, haciendo radicar en la palabra poética la potencia de resistir a las condiciones de la vida favelada. En tanto, hacia el final del poema, es la voz de la hija la que recoge todas las otras voces, no solo hace coro con ellas, sino que además resuena, desarrollando su propia resistencia al guardar las voces-experiencias por las cuales las mujeres anteriores a ella pasaron (Feldman y Silvestre, 2015, p. 108). ${ }^{13}$ De esta forma creemos, en el poema antes citado se hace presente la formulación y negociación de sentidos, con especial atención en la cuestión de género, referidos por Thomaz, en tanto se hace radicar en la voz femenina y en la poesía la posibilidad de resistir y cambiar el devenir de sujetos colonizadas de varias generaciones de mujeres, gesto de resistencia que se vuelve a reiterar en el poema, "Na mulher, o tempo" del cual citamos el siguiente fragmento:

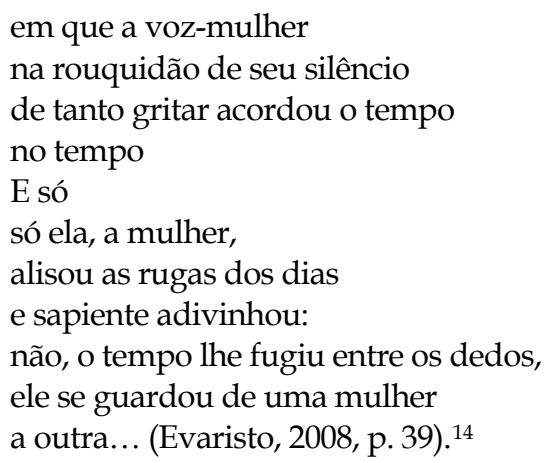

Respecto de los versos citados Feldman y Silvestre (2015, p. 104-105) señalan que la relación voz-mujer, como motivo lírico del poemario de Evaristo, busca hacer hablar a las voces calladas en el hacer literario en general. Al mismo tiempo, el hecho de juntar ambos vocablo, es decir, "voces" con "mujeres" por medio de un guion, se transforma en un empoderamiento del discurso, pues las voces y las mujeres tienen la misma connotación: trayectorias femeninas mostradas por la ancestralidad, afirmación de existencia, a partir de un colectivo. ${ }^{15}$ Dicha

\footnotetext{
${ }^{13} \mathrm{Al}$ respecto las autoras señalan: “Ao 'recolher' as vozes do passado, a voz futura da filha, também se liga às vozes de suas ancestrais, e também ecoa, mas ela não apenas ecoará por necessidade, mas ressoará, ou seja, dará sua contribuição a essa nova voz que surge da coletividade (Feldman y Silvestre, 2015, p. 108).

14 en el que la voz-mujer /en la ronquera de su silencio/de tanto gritar despertó el tiempo/a tiempo/Y solo Sola ella, la mujer/Alisó las arrugas de los días /Y sabia adivinó:/No, el tiempo no se le escapó entre los dedos/ él se guardó de una mujer/ a otra... (traducción mía)

${ }^{15}$ La cita en su idioma original dice: “Mas, ao mesmo tempo, o fato de juntar o vocábulo 'vozes' ao vocábulo 'mulheres', por meio de hífen, transforma-se em um empoderamento do discurso, pois, as vozes e as mulheres têm a mesma conotação: trajetórias femininas mostradas pela ancestralidade; afirmação de existência, a partir de um coletivo" (Feldman y Silvestre, 2015, p. 104-105).
} 
referencia al título del poema "Vozes-mulheres", anteriormente abordado en este análisis, creemos es válido para los versos "Na mulher, o tempo", en tantos en ellos se presenta nuevamente la relación voz-mujer, relación que tal como sostienen las investigadoras antes citadas, afirma la intención de abrir los espacios tradicionalmente vedado para las mujeres, como es el caso de la literatura. ${ }^{16}$ Por otra parte, el vínculo voz-mujer, alude a la conformación de un colectivo femenino afrodescendiente, lo que en los versos anteriores se presenta a través de la alusión a un tiempo que no se escapa, sino que se guarda de una mujer a otra y a otra, infinitamente. Lo anterior, decimos, muestra en el texto lo colectivo y lo múltiple como otra forma de ser sujeto, dicha multiplicidad subjetiva afirmamos, desde el punto de vista gráfico, se enfatiza a través del uso de los puntos suspensivos usados tanto en el título del poema como hacia el final de los versos citados. Ahora bien, atendiendo a las de la metáfora de la voz como alusión de identidad y cultura, creemos que en los textos aquí analizados dicha metáfora entrama lo femenino con lo etnocultural. Respecto de dicho entramado tomamos los planteamientos de Soledad Fallabela Luco (2006, p. 72) quien indica que lo oral es un elemento clave para comprender lo femenino de la escritura de mujeres, en tanto la cultura de las mujeres es más cercana a esta forma de expresión, dada su histórica exclusión de la norma pública letrada (derecho a la educación formal, participación ciudadana y autoría). Si bien Fallabela Luco refiere al caso específico de las poetas mapuche, las cuales indica han sido capaces de productivizar esta postergación, revitalizando la norma letrada (2006, p. 72). Para el caso de Poemas da recordação e outros movimentos, creemos también es valida la relación planteada por la investigadora chilena, dado que la "escrivivencia", como Evaristo define su escritura poética y narrativa, son letras que se asientan en la voz y experiencia singular y colectiva de las mujeres negras (Miranda, 2019, p. 18), ${ }^{17}$ definición que decimos tensiona una serie de dicotomías canónicas, como la de arte/vida, oralidad/ escritura, desbordando con ello las dualidades logocéntricas como lo sugiere la misma configuración del concepto. Conforme a lo antes señalado decimos que la metáfora de la voz se presenta a veces como eco, susurro o lamento, en tanto en otros momentos deviene grito, conjurando el silencio, según se expresa en el poema "Da conjuração dos versos" del cual citamos un fragmento:

- nossos poemas conjuram e gritam -

O silêncio mordido.

rebela e revela

nossos ais

e são tantos os gritos

que a alva cidade

de seu imerecido sono,

despertar em pesadelos

E pedimos

que as balas perdidas

percam o nosso rumo

e não façam do corpo nosso,

os nossos filhos, o alvo [...]

E não há mais

Quem morda a nossa língua.

O nosso verbo solto

\footnotetext{
${ }^{16}$ En relación a ello Liliane Nogueira Monteiro (2021, p. 2) nos recuerda que para las mujeres negras y blancas la literatura fue por mucho tiempo espacio de exclusión y muchas veces de negación de su participación.

${ }^{17} \mathrm{Al}$ respecto la autora señala "Não obstante, o fato de a escrevivência posicionar abertamente um sujeito social (a mulher negra) como sujeito da fala (do texto literário) - ou seja, visibilizar a autora negra produzindo abertamente seu universo ficcional assentada sob o chão da sua experiência (que é pessoal, mas também histórica, política, coletiva, como a de todos os indivíduos em sociedade)" (Miranda, 2019, p. 18).
} 
conjugou antes

o tempo de todas as dores

E o silêncio escapou.

ferindo a ordenança.

e hoje o anverso

da mudez é a nudez

do nosso gritante verso

que se quer libre (Evaristo, 2008, p. 87-88)..$^{18}$

Pues bien, en los versos antes citados es posible evidenciar que la voz se transforma en grito, el cual alude tanto a la violencia colonial, como a la forma de expresión que el subalterno encuentra en este contexto. En relación a lo anterior, Arruda de Souza $(2019$, p. 13) nos plantea que la poesía de Conceição Evaristo es conocida por develar aquello que hace mucho permanecía encubierto: la voz negra femenina, una voz que paradojalmente siempre existió, pero era repetida en oídos ensordecidos. La autora además plantea que ahora, los gritos de la diferencia pueden ser oídos y los oídos son colocados a prueba, pues reconocen y vislumbran la ausencia traída por los signos cuando antes acreditábamos que ellos traían la presencia. ${ }^{19}$ En conformidad a lo anterior, afirmamos que los gritos que en los versos despiertan al tiempo, forman parte de la cadena semántica que alude metonímicamente a la voz y sus significados, alegorizando la enunciación de las mujeres negras, en tanto sujetos colonizadas. En este sentido podemos afirmar que estos hacen presente/audible lo ausentes/silenciado de las significaciones hegemónicas. ${ }^{20}$

Ahora bien, como ya antes habíamos señalado, el lenguaje poético para Genette (1970), corresponde a todo lo que escapa de los marcos de la lingüística denotativa. Más allá de las limitaciones de este planteamiento que obedece a la lógica dicotómica norma-anomalía, nosotros rescatamos el rebasamiento de las estructuras duales del logos occidental sugerido por el autor, a través de la proliferación de sentidos que despliegan los tropos y el lenguaje literario en general. Es decir, ese "excedente de sentido" al que refiere Paul Ricoeur, como desborde de las denotaciones del signo lingüístico y los significados semánticos (1995, p. 58). Así mismo, a partir de que esta proliferación o excedente, planteamos se establece una relación entre la palabra poética con la oralidad tradicional de los pueblos ancestrales, refiriendo con ello a formas epistémicas anteriores/diferentes a la preeminencia de la escritura. Ahora bien, en este poema es posible advertir la presencia de una palabra devenida en grito, la que muerde el silencio según se declara en primera estrofa, aludiendo con ello a las posibilidades de resistencia radicadas en el lenguaje. Lo que es reafirmado en los versos siguientes con la relación homófona de las palabras rebela/revela, que hace radicar en la palabra oral y la poesía la potencialidad de resistir a las condiciones de marginalidad impuestas por el sistema colonizador. De este modo afirmamos que en el poema citado poesía, grito, verbo suelto y lengua, constituyen la cadena semántica de la voz como metáfora, la que afirmamos ilumina en el texto el espacio liminal de proliferación de sentidos que caracteriza a la palabra oral y el lenguaje poético. Conforme a lo antes señalado, afirmamos que dicha palabra liberada constituye el lenguaje indómito de la hablante de Huinao, al que antes referimos, así como también, los versos gritando libertad de la

\footnotetext{
${ }^{18}$ Nuestros poemas conjuran y gritan

El silencio mordido./rebela y revela/nuestros ais/y son tantos gritos/que al amanecer la ciudad/de su sueño inmerecido,/despierta en pesadillas

Y pedimos /que las balas perdidas/pierdan nuestro rumbo/y no hagan del cuerpo nuestro,/o el de nuestros hijos, el objetivo [...]

Y no hay más/quien muerda nuesta lengua./nuestro verbo suelto/conjugó antes/el tiempo de todos los dolores

$\mathrm{Y}$ el silencio se escapo./hiriendo la ordenanza./y hoy el anverso/de la mudez es la desnudez/ de nuestro verso que grita/que quiere ser libre (traducción mía).

${ }^{19}$ La cita en portugués dice: “A poesia de Conceição Evaristo é conhecida por desvelar aquilo que há muito permaneceu encoberto: a voz negra feminina, uma voz que, paradoxalmente, sempre existiu, mas era ecoada em ouvidos ensurdecidos Agora, os tantos gritos perdidos da diferença podem ser ouvidos e os ouvidos são colocados à prova, pois reconhecer e vislumbrar a ausência trazida pelos signos quando antes acreditávamos que eles traziam a presença".

${ }^{20}$ Relacionado con esto último, cabe señalar que Evaristo plantea que para ella la escritura es un modo de herir el silencio impuesto (Monteiro, 2021, p. 5), conforme a lo cual decimos que, en el poema antes citado, la voz devenida en gritos y en exclamaciones, reitera el compromiso escritural declarado por la autora de hacer audible el discurso de los silenciados.
} 
voz lírica de Evaristo. Conforme a lo antes planteado, podemos sostener que en los poemarios Walinto y Poemas da recordação e outros movimentos aquí analizados, se pueden poner en relación a partir del destino común de sujetos colonizadas desde donde se enuncian sus hablantes.

\section{Conclusiones}

En el presente análisis hemos abordado los poemarios Walinto de Graciela Huinao y Poemas da recordação e outros movimentos de Conceição Evaristo, desde la perspectiva de la retórica subalterna, entendiendo esto como la evidenciación de las metáforas que subvierten el discurso colonizador. En conformidad a ello, vinculamos las obras de Huinao y Evaristo a través de la metáfora de la voz, la cual decimos configura el espacio común de apertura hacia lo otro, como eco, resonancia y/o grito, textualizando la preeminencia connotativa de las culturas orales y las concepciones contemporáneas de las subjetividades múltiples y plurales.

Cabe señalar que en las obras que han conformado nuestro corpus, es decir Walinto y Poemas da recordação e outros movimentos, las sujetos líricas se enuncian desde una voz femenina mapuche y afrobrasileña, respectivamente, siendo posible hacer dialogar a ambas hablantes a partir de su devenir compartido de sujeto colonizadas. Dicho diálogo, bajo nuestra perspectiva de la retórica subalterna, lo hemos llevado a cabo mediante la voz como metáfora y sus significantes referidos al canto, lengua, eco, resonancia, poesía, grito; entre otros, los que decimos entrelazan el destino colectivo e individual de las sujetos líricas de los dos textos.

Conforme a lo anterior, en el poemario Walinto, podemos señalar que nos hemos centrado en la evidenciación de la retórica subalterna en tres poemas, "La voz de mi padre", "Los cantos de José Loi" y "Nawel buta", en los cuales afirmamos, la metáfora de la voz se presenta como recurso retórico que alude a la preeminencia oral de la cultura mapuche y a la polisignificancia propia del mapuzungun. Considerando esto decimos que en dicho poemario palabra y lenguaje funcionan como recursos retóricos para referir a la tradición oral del pueblo mapuche, recomponiendo con ello las coordenadas del wallmapu originario. Del mismo modo afirmamos que en el texto de Huinao se hace radicar en la palabra oral/ancestral y en la palabra poética la potencialidad de resistir a la destrucción colonizadora, lo que a momentos en la obra se expresa como larga noche de exterminio. Respecto del dominio colonial, como establecimos en este análisis, la colonización epistémica se puede entender como imposición de la rigidez y permanencia de la letra escrita sobre la preeminencia connotativa de las oralidades originarias. Dicha rigidez y permanencia devenida de la univocidad significante y radicada en la denotación, decimos es desbordada por la palabra oral/ancestral y la poesía en su multiplicidad significante.

Pues bien, conforme a lo anterior, sostenemos que la lengua tradicional del pueblo mapuche rebasa las estructuras duales del logos occidental, diseminando las significaciones en la pluralidad de sentidos desplegados por los fonemas del mapuzungun, diseminación significante que ha momentos en el texto, encuentra como vehículo de restitución y/o conservación la palabra poética, en tanto en otras lo hace descifrando el lenguaje de la naturaleza. En sentido afirmamos que en Walinto se enuncia una sujeto que nombra su diferencia a través de la articulación de voces plurales y ancestrales, así como también reconociéndose en correspondencia con los elementos de la naturaleza, en este sentido afirmamos que en los versos voz, canto y lengua, textualizan la preeminencia connotativa de las culturas orales y las concepciones contemporáneas de las subjetividades múltiples y plurales.

Ahora bien, en Poemas da recordação e outros movimentos, nos centramos en el análisis de los poemas "Voces-mulheres", "Na mulher, o tempo" y "Da conjuração dos versos", en los cuales pudimos evidenciar que la metáfora de la voz se hace presente como eco, lamento, resonancia, y/o grito; alegorizando de este modo la preeminencia de la oralidad de las culturas de origen africano. Respecto de lo anterior, como constatamos en el desarrollo de esta investigación, cabe señalar que reconstruir el camino de la oralidad originaria de los pueblos afrodescendientes es complejo, en tanto significa realizar un viaje trasatlántico, donde nos encontramos con los heterogéneos orígenes geográficos y culturales de quienes fueron traídos al continente para ser esclavizados. Pues bien, teniendo en cuenta dicha diversidad cultural, planteamos que la 
oralidad tradicional es un elemento articulador de la identidad afrodescendiente latinoamericana, que ha posibilitado la conservación y perpetuación de sus coordenadas identitarias ancestrales dentro de la historia de la colonización.

Respecto del poema "Vozes-mulheres" podemos indicar que se constituye en referencia ineludible en el intento de realizar un acercamiento a la poética de la autora. Al respecto cabe señalar que en este poema la enunciación de la hablante se articula o entrama con las voces de la bisabuela, la abuela, la madre y la hija, interpelando con ello la enunciación singular del sujeto colonizador. También señalamos que, en la obra de Evaristo, desde un perspectiva contemporánea, se puede constatar un compromiso por hacer audible la voz-eco-lamento de las mujeres negras esclavizadas y marginadas por la historia colonial. Este gesto de resistencia en la palabra creemos se vuelve a reiterar en el poema en el poema, "Na mulher, o tempo", en el cual vuelve a estar presente la relación voz-mujer, vínculo que en el poemario alude a la conformación de un colectivo de mujeres afrobrasileñas, refiriendo con ello tanto a una estrategia de resistencia a la marginación social de dicha colectividad, así como también desde el punto de vista de las teorías contemporáneas a lo colectivo y lo múltiple como otra forma de ser sujeto. Ahora bien, según pudimos constatar en este análisis, en Poemas da recordação e outros movimentos, la metáfora de la voz se presenta a veces como eco, susurro o lamento, en tanto en otros momentos deviene grito como sucede en "Da conjuração dos versos", el cual decimos alude tanto a la violencia colonial, como a la forma de expresión que el subalterno encuentra en este contexto.

Ahora bien, como referimos en el desarrollo de este análisis, más allá de las limitaciones de los planteamientos que delinean el lenguaje poético en contraposición con el lenguaje denotativo, nosotros rescatamos de este el rebasamiento de las estructuras duales del logos occidental que despliega la poesía. Excedente de sentido que planteamos establece una relación entre palabra poética y la oralidad tradicional de los pueblos ancestrales, refiriendo con ello a formas epistémicas anteriores/diferentes a la preeminencia de la escritura.

\section{Referências}

ASSIS, Eduardo Duarte de (2006). O Bildungsroman afro-brasileiro de Conceição Evaristo. Estudos Feministas, Florianópolis, v. 14, n. 1, p. 305-308. Disponível em: https://www.scielo.br/j/ref/a/g7gPJT4f9yzqMyFyLxR6HBb/. Acesso em: 10 out. 2021.

CARDOSO, Carlos Guerra (2015). La poética adivinatoria de Ifa: transculturación yórùbà en la escritura caribeña. 698f. Tese (Doutorado em Literatura y Teoría de la Literatura) - Universidad de las Palmas de la Gran Canaria, Las Palmas de Gran Canaria. Disponível em: https://accedacris.ulpgc.es/bitstream/10553/18397/4/0727165_00000_0000.pdf Acesso em: 10 out. 2021.

CARRASCO MUÑOZ, Ivan (2000). Poesía mapuche etnocultural. Anales de Literatura Chilena, n. 1, p. 195-214.

CARRASCO MUNÕZ, Ivan (2010). Cherruve...i Primera novela mapuche?... Lengua y Literatura Mapuche, n. 14, p. 27-36. Disponível em: https://revistas.ufro.cl/ojs/index.php/indoamericana/article/view/694. Acesso em: 10 out. 2010.

DERRIDA, Jacques (1968). La diferencia/[differánce]. Santiago: Escuela de Filosofía Universidad ARCIS. E-book. Disponível em: https://www.philosophia.cl/biblioteca/Derrida/La\%20Diferencia.pdf. Acesso em: 10 out. 2021.

EVARISTO, Conceição (2008). Poemas da recordação e outros movimentos. Rio de Janeiro: Malê.

FALLABELA LUCO, Soledad (2006). Hilando en la memoria: la poesía de poetas mapuche contemporáneas: Millapan, Curriao, Huinao y Panchillo. Hispamérica, ano 35, n. 105, p. 69-82. Disponível em: https://www.jstor.org/stable/20540743?refreqid=excelsior\%3A4e12951329b2fe5b9f0ba0fc088e065e. Acesso em: 10 out. 2021.

FELDMAN, Alba Krishna Topan; SILVESTRE, Nelci Alves Coelho (2015). "Vozes-mulheres" do terceiro mundo: a perspectiva de Conceiçao Evaristo. Anuário de Literatura, Florianópolis, v. 20, n. 1, p. 96-111. Disponível em: https://periodicos.ufsc.br/index.php/literatura/article/view/2175-7917.2015v20n1p96. Acesso em: 12 out. 2021.

GENETTE, G. (1970). Lenguaje poético, poética del lenguaje. Buenos Aires: Nueva visión. 
HUINAO, Graciela (2009). Walinto. Santiago: Cuarto Propio.

MIRANDA, Fernanda Rodrigues de (2019). Ponciá Vicêncio: Narrativa e contramemória colonial. Anuário de Literatura, Florianópolis, v. 24, n. 2, p. 15-29. Disponível em: https:// periodicos.ufsc.br/index.php/literatura/article/view/2175-7917.2019v24n2p15/41875. Acesso em: 10 out. 2021.

MONTEIRO, Liliane Nogueira (2016). A representação da mulher negra na literatura brasileira. In: SIMPÓSIO LINGUAGENS E IDENTIDADES DA/NA AMAZÔNIA SUL-OCIDENTAL, 10., COLÓQUIO INTERNACIONAL AS AMAZÔNIAS, AS ÁFRICAS E AS ÁFRICAS NA PAN-AMAZÔNIA, 8., Rio Branco. Anais [...] Rio Branco: UFAC. Disponível em: https://docplayer.com.br/29462632-A-representacao-da-mulhernegra-na-literatura-brasileira-liliane-nogueira-monteiro-1.html. Acesso em: 10 out. 2021.

MORA CURRIAO, Maribel (2018). Muestra de poesía mapuche. Trazas poéticas sobre una cartografía indígena incesante. Anales de la Universidad de Chile, n. 13 p. 165-218. Disponível em: https://anales.uchile.cl/index.php/ANUC/article/view/49003. Acesso em: 10 out. 2021.

MORA, Ziley (2001). Filosofía mapuche: palabras arcaicas para despertar el ser. Concepción: Kushe. Disponível em: https://www.folkloretradiciones.com.ar/literatura/Mora\%20Penros\%20Ziley\%20\%20Filosofia\%20Mapuche.pdf. Acesso em: 10 out. 2021.

MORAGA, Fernanda (2009). A propósito de la "diferencia": poesía de mujeres mapuche. Revista Chilena de Literatura, n. 74, p. 225-239.

MOSCIATTI, Ezio. Graciela Huinao: si un verso mío fortalece la identidad de los niños mapuches, soy $\begin{array}{llllll}\text { feliz. } & \text { biobiochile.cl. } & 10 & \text { out. } & 2012 . & \text { Disponível }\end{array}$ https:/ / www.biobiochile.cl/noticias/2012/10/10/graciela-huinao-si-un-verso-mio-fortalece-la-identidadde-los-ninos-mapuche-soy-feliz.shtml. Acesso em: 10 out. 2021.

RAMA, Ángel (1998). La ciudad letrada. Montevideo: Arca.

RICOEUR, Paul (1995). Teoría de la interpretación: discurso y excedente de sentido. México D. F.: Siglo XXI.

SANTOS, Daiana Nascimento dos (2011). Imaginarios y representaciones en la tradición oral africana y latinoamericana. Acta literaria, n. 42, p. 145-150. Disponível em: https://www.scielo.cl/scielo.php?script=sci_arttext\&pid=S0717-68482011000100010. Acesso em: 10 out. 2021.

SOUZA, Rosana Arruda de (2019). Memória rastro em poemas de Conceição Evaristo. Anuário de Literatura, Florianópolis, v. 24, n. 1, p. 13-22. Disponível em: https://periodicos.ufsc.br/index.php/literatura/article/view/2175-7917.2019v24n1p13. Acesso em: 10 out. 2021.

THOMAZ, Paulo C. (2015) Des-reterritorialização: percursos possíveis do romance afro-brasileiro recente. Estudos de literatura brasileira contemporânea, n. 15, p. 21-35, jan./jun. Disponível em: https://www.scielo.br/j/elbc/a/vsK5wPrfL9X76hhtsNw7spH/?format=pdf. Acesso em: 10 out. 2021.

\section{Nota}

Este artículo fue financiado por el Fondo de Cultura y las Artes, Fondo de Fomento del Libro y la Lectura, línea de Becas Chile Crea, 2020. 